TITLE:

\title{
Methylovulum miyakonense gen. nov., sp. nov., a type I methanotroph isolated from forest soil.
}

$\operatorname{AUTHOR}(S)$ :

Iguchi, Hiroyuki; Yurimoto, Hiroya; Sakai, Yasuyoshi

\section{CITATION:}

Iguchi, Hiroyuki ...[et al]. Methylovulum miyakonense gen. nov., sp. nov., a type I methanotroph isolated from forest soil.. International journal of systematic and evolutionary microbiology 2011, 61(4): 810-815

\section{ISSUE DATE:}

2011-04

URL:

http://hdl.handle.net/2433/197236

\section{RIGHT:}

This is an author accepted manuscript (AAM) that has been accepted for publication in International Journal of Systematic and Evolutionary Microbiology that has not been copy-edited, typeset or proofed. The Society for General Microbiology (SGM) does not permit the posting of AAMs for commercial use or systematic distribution. SGM disclaims any responsibility or liability for errors or omissions in this version of the manuscript or in any version derived from it by any other parties. The final version is available at http://dx.doi.org/10.1099/ijs.0.019604-0; This is not the published version. Please cite only the published version.; この論文は出版社版でありません。引用の際には出版社版をご磪認じ 利用ください。 
Methylovulum miyakonense gen. nov., sp. nov., a novel type I methanotroph from a forest soil in Japan

Hiroyuki Iguchi, Hiroya Yurimoto and Yasuyoshi Sakai

9 Division of Applied Life Sciences, Graduate School of Agriculture, Kyoto

University, Kitashirakawa-Oiwake, Sakyo-ku, Kyoto 606-8502, Japan.

Author for correspondence: Yasuyoshi Sakai. Tel: +81 75753 6385. Fax: +81

75753 6454. E-mail: ysakai@kais.kyoto-u.ac.jp

Subject category: Proteobacteria.

Runnning title: Methylovulum miyakonense gen. nov., sp. nov.

Abbreviations: pMMO, particulate methane monooxygenase; sMMO, soluble methane monooxygenase; NMS, nitrate mineral salt.

The GenBank/EMBL/DDBJ accession numbers for the 16S rRNA gene, pmoA, mmoX and nifH sequences of strain HT12 are AB501287, AB501285, AB501286 and AB524080, respectively. 
2

3

4

5

6

7

\section{ABSTRACT}

A novel methanotroph, strain $\mathrm{HT}_{12}{ }^{\mathrm{T}}$, was isolated from a forest soil in Japan. Strain HT12T is a Gram־negative, aerobic, non-motile, coccoid, pale brown colored bacterium. The strain only grows on methane and methanol as the sole carbon and energy source. Cells grow at $5-34^{\circ} \mathrm{C}$ (optimum $24-32^{\circ} \mathrm{C}$ ). The strain possesses both particulate and soluble methane monooxygenases, and employs the ribulose monophosphate pathway for formaldehyde assimilation. The major cellular fatty acids are $16: 0(46.9 \%)$ and $14: 0(34.2 \%)$, whereas unsaturated $\mathrm{C}_{16}$ fatty acids which are signature for type I methanotrophs are absent. Comparative sequence analysis of the 16S rRNA gene showed that the most closely related strains are Methylosoma difficile LC $2^{\text {T }}$ (93.1\% identity) and Methylobacter tundripaludum SV96 ${ }^{\mathrm{T}}$ (92.6\% identity). Phylogenetic analysis of the $p m o A$ gene indicated that strain HT12 $2^{\mathrm{T}}$ represents a distinct branch, and that the $p m o A$ amino acid sequence displayed $7 \%$ divergence from the closest species. The DNA G $+\mathrm{C}$ content is $49.3 \mathrm{~mol} \%$. Therefore we propose that strain $\mathrm{HT}_{12} 2^{\mathrm{T}}$ represents a novel genus and species, Methylovulum miyakonense gen. nov., sp. nov. Strain HT12 $\left(=\right.$ NBRC $106162^{\mathrm{T}}=\mathrm{DSM} 23269^{\mathrm{T}}=$ ATCC BAA-2070T $)$ is the type strain. 
Methanotrophs are a group of aerobic bacteria that utilize methane as the sole carbon and energy sources. They inhabit soils, wetlands, sediments, fresh and marine waters, lakes and peat bogs, and work as biofilters to reduce methane emissions into the atmosphere (Hanson \& Hanson, 1996).

Methanotrophs are divided into two major subgroups. The type I methanotrophs, which belong to $\gamma$-Proteobacteria comprise the genera Methylomonas, Methylobacter, Methylocaldum, Methylomicrobium, Methylosarcina, Mehylohalobius, Methylosphaera, Methylothermus, Methylosoma and Methylococcus. The type II methanotrophs, which belong to $\alpha$-Proteobacteria comprise the genera Methylosinus, Methylocystis, Methylocella and Methylocapsa. Recently methanotrophs which are not within the classical types of characteristics have been reported. Crenothrix polyspora and Clonothrix fusca, which form filaments consisting of groups of sheathed cells were considered to be type I methanotrophs from phylogenetic traits (Stoecker et al., 2006; Vigliotta et al., 2007). The extremely acidophilic methane-oxidizing bacteria isolated from geothermal vents belong to the phylum, Verrucomicrobia rather than Proteobacteria (Pol et al., 2007; Dunfield et al., 2007; Islam et al., 2008).

In upland soils the methane concentration is low at or below atmospheric levels, but the diverse methanotrophs are active in response to the changes of temperature, soil moisture and nitrogen availability (Knief et al., 2003; Kolb et al., 2005; Horz et al., 2005; Mohanty et al., 2006; Mohanty et al., 2007; Singh \& Kashyap, 2007). Although the analysis using the molecular markers (i.e., $16 \mathrm{~S}$ rRNA gene, $p m o A$ gene, $m m o X$ gene and PLFAs) can clarify the ecology of methanotrophs and even indicate the presence of new methanotrophs at the site, the research on physiology and biochemistry of isolated metahnotorphs on site is significant to reveal their precise work. In this paper, we report on the isolation and the characterization of the methanotroph from a forest soil. 
1 We propose a new genus, Methylovulum gen. nov., and the new species Methylovulum

3

Soils from the forest in Hyogo, Japan $\left(35^{\circ} 28^{\prime} \mathrm{N}, 134^{\circ} 33^{\prime} \mathrm{E}\right)$ were collected in July 2006. The soil sample was combined with $5 \mathrm{ml}$ nitrate mineral salt (NMS) medium (Whittenbury et al., 1970) at $\mathrm{pH} 6.8$ in a $25 \mathrm{ml}$ vial. The vial was sealed with a butyl rubber cap and with a crimped aluminum seal, after which $5 \mathrm{ml}$ methane was added to achieve a $20 \%(\mathrm{v} / \mathrm{v})$ atmospheric concentration. The vial was incubated at $28^{\circ} \mathrm{C}$ with shaking. Turbid enrichment cultures were sub-cultured in fresh NMS medium. The enrichment culture was serially diluted and spread onto NMS agar plates. The plates were incubated for 2 weeks at $28^{\circ} \mathrm{C}$ in a jar filled with a methane/air mixture. A colony was inoculated to liquid NMS medium with methane and 0.01\% tryptone (Bacto Tryptone, Becton, Dickinson and Company), and cultivated. The cultivation in liquid medium and single colony isolation from agar plates were repeated until a single colony morphotype was obtained. Analysis of cell uniformity by light microscopy, and the absence of growth on Luria-Bertani (LB) agar (1\% tryptone, $0.5 \%$ yeast extract, $1 \%$ $\mathrm{NaCl}$ ) or tryptic soy agar (Becton, Dickinson and Company) were used as criteria for assessment of culture purity. Since the addition of tryptone stimulated the growth of the isolate, the isolate was usually cultivated in liquid NMS medium with methane and $0.01 \%$ tryptone, and was subcultuerd at 2-4 week intervals.

Morphological observations were performed using phase-contrast microscopy. Cyst formation was observed by the method of Vela \& Wyss (1964). Cell fixation and observation using electron microscopy were performed at Tokai Electron Microscopy Analysis (Aichi, Japan). Exponentially growing cells were fixed with $2 \%$ glutataraldehyde and $2 \%$ para-formaldehyde in $0.1 \mathrm{M}$ phosphate buffer ( $\mathrm{pH} 7.4)$. After 
cells were washed with $0.1 \mathrm{M}$ phosphate buffer, they were subjected to a secondary fixation with $2 \%$ osmium tetroxide in $0.1 \mathrm{M}$ phosphate buffer. Cells were then dehydrated with 50\%, 70\%, 90\% and 100\% ethanol. The cells were embedded in Quetol 812 (Nisshin EM) / methyl oxirane (1:3), and polymerized. Sections of $70 \mathrm{~nm}$ were cut on LKB 2088 ultrotome V (LKB-Produkter AB), stained with uranyl acetate and lead stain solution (Sigma-Aldrich), and viewed by JEM-1200EX transmission electron microscopy (JEOL) operating at $80 \mathrm{kV}$.

Analysis of the ability to utilize various carbon sources was tested in liquid NMS medium. Methanol and formaldehyde were added at 10-50 mM, and formamide and ethanol were added at $0.1 \%(\mathrm{v} / \mathrm{v})$. The following compounds were added to the medium at concentrations of $0.1 \%(\mathrm{w} / \mathrm{v})$ : methylamine, formate, glucose, sucrose, galactose, lactose, fructose, citrate, succinate, pyruvate, acetate and tryptone. Utilization of various nitrogen sources was tested in liquid NMS medium in which $\mathrm{KNO}_{3}$ was replaced by one of the following compounds at $0.05 \%(\mathrm{w} / \mathrm{v}) ; \mathrm{NH}_{4} \mathrm{Cl}, \mathrm{NaNO}_{2}$, urea, peptone, tryptone, yeast extract, casamino acid, glycine, alanine, lysine, arginine, glutamate, glutamine, aspartate, asparagine, tryptophan, methionine, threonine, cysteine and histidine. The temperature range for growth was tested in liquid NMS medium at $5,10,15,20,24,28,32,34$ and $37^{\circ} \mathrm{C}$. The effect of $\mathrm{pH}$ was tested at $28^{\circ} \mathrm{C}$ in liquid NMS medium of which $\mathrm{pH}$ was adjusted by phosphate buffer (6.0-7.5) or citrate/phosphate buffer (5.0-6.5) at concentrations of 10 and $25 \mathrm{mM}$. Growth was also checked in liquid NMS medium without using any buffer, but using $\mathrm{HCl}$ or $\mathrm{NaOH}$ to adjust $\mathrm{pH}(5.0-8.0)$. To determine the optimum salt concentrations, $\mathrm{NaCl}$ was added to liquid NMS medium at concentrations of $0.1-0.5 \%$.

For enzyme assays cells grown on methane were suspended in $20 \mathrm{mM}$ Tris- $\mathrm{HCl}$ buffer ( $\mathrm{pH}$ 7.5) containing $5 \mathrm{mM} \mathrm{MgCl} 2,10 \%$ glycerol and $1 \mathrm{mM}$ dithiothreitol, and were 
disrupted by sonication. After the sample was centrifuged at 5,000 $\mathrm{x} g$ for $30 \mathrm{~min}$, the resulting supernatant was subjected to the following assays. The activity of 3-hexulose-6-phosphate synthase was measured by the disappearance of formaldehyde (Kato, 1990). The activity of 6-phospho-3-hexuloisomerase was assessed as described by Arfman et al. (1990).

The cellular fatty acid analysis was performed at TechnoSuruga Laboratory (Shizuoka, Japan). Exponentially growing cells on methane in NMS medium were washed with $0.9 \% \mathrm{NaCl}$ solution, freeze-dried and sent for the analysis. There, the cells were methylated and the methyl esters were subjected to gas chromatography. The fatty acids composition was determined by Sherlock Microbial Identification System (MIDI Inc.). The $\mathrm{G}+\mathrm{C}$ content was analyzed at TechnoSuruga Laboratory. The DNA was extracted by the method of Ezaki et al. (1990). G + C content was measured by HPLC by the method of Katayama-Fujimura et al. (1984).

For PCR amplification the following primer sets were used; $27 \mathrm{f}-1492 \mathrm{r}$ for the 16S rRNA gene (Weisburg et al., 1991), A189-mb661 for the pmoA gene (Holmes et al., 1995; Costello \& Lidstrom, 1999), mmoXA-mmoXB for the mmoX gene (Auman et al., 2000) and PolF-PolR for the nifH gene (Poly et al., 2001). PCR reactions were performed with Ex Taq polymerase (Takara Bio) using 30 cycles of $97^{\circ} \mathrm{C}$ for $30 \mathrm{~s}, 55^{\circ} \mathrm{C}$ for $30 \mathrm{~s}$ and $72^{\circ} \mathrm{C}$ for $30 \mathrm{~s}(p m o A$ and nifH) or $90 \mathrm{~s}(16 \mathrm{~S}$ rRNA and $m m o X)$. The products were sequenced using BigDye Terminator v3.1 Cycle Sequencing Kit and ABI 3130 genetic analyzer (Applied Biosystems). The 16S rRNA gene sequences (positions 28-1491, according to the International Union of Biochemistry nomenclature for Escherichia coli 16S rRNA), the deduced amino acid sequences of the $p m o A$ gene (169 amino acids) and the deduced amino acid sequence of the $\operatorname{mmoX}$ gene (411 amino acids), respectively, were aligned with homologous sequences from the database using CLUSTAL W 
program version 1.83 (http://clustalw.ddbj.nig.ac.jp/top-e.html). Phylogenetic trees were constructed by the neighbor-joining method with Kimura two-parameter model and were evaluated by bootstrap analysis based on 100 resampling replicates using CLUSTAL W program.

(1)

Strain HT12 ${ }^{\mathrm{T}}$ was obtained from a forest soil sample collected in Hyogo prefecture, Japan, by the enrichment culture technique using methane as the sole carbon source. After several enrichments of the culture, strain $\mathrm{HT}_{12} 2^{\mathrm{T}}$ was isolated as a single colony on an NMS agar plate using methane as the carbon source. The culture purity was verified by the failure to grow on LB agar and tryptic soy agar plates. This strain utilized methane in liquid NMS medium at a specific growth rate $(\mu)$ of $0.0093 \mathrm{~h}^{-1}$ at the exponential phase.

Morphological and physiological characteristics of strain $\mathrm{HT}_{12}^{\mathrm{T}}$ are summarized in Table 1. Two-week old colonies of strain $\mathrm{HT}^{\mathrm{T}} 2^{\mathrm{T}}$ were round, 1-2 $\mathrm{mm}$ in diameter, convex, pale brown in color and exhibited a smooth surface and an entire edge. As revealed by phase-contrast microscopy, the cells were non-motile, and coccoids or short rods that were 1.5-2.5 $\mu \mathrm{m}$ in length and 1.0-2.0 $\mu \mathrm{m}$ in width (Fig. 1a). Cysts were not observed on cells cultured in liquid or solid medium for 1 month. Electron microscopy analysis of ultrathin sections of cells revealed bundles of disk-shaped vesicles that are indicative of the typical intracytoplasmic membrane (ICM) of type I methanotrophs (Fig. 1b, c). The large inclusions of low electron density, presumably comprising poly- $\beta$-hydroxybutyrate granules, were also observed in the cells.

Strain HT12 $12^{\mathrm{T}}$ only grew on methane and methanol $(10-50 \mathrm{mM})$. None of the other carbon sources tested were utilized. Of the nitrogen sources tested, nitrate, $\mathrm{NH}_{4} \mathrm{Cl}$, glutamine and casamino acids were utilized. To lesser extent, cysteine, peptone and 
tryptone were also utilized. No growth was observed in nitrogen-free medium although the nifH gene was amplified by PCR. Strain $\mathrm{HT}_{12}^{\mathrm{T}}$ is a mesophile that grows at temperatures ranging from 5 to $34{ }^{\circ} \mathrm{C}$. Optimal growth was observed at $24-32{ }^{\circ} \mathrm{C}$. Aggregation of cells was observed at temperatures below $20^{\circ} \mathrm{C}$. The strain was sensitive to $\mathrm{NaCl}$, which inhibited growth at concentrations above $0.2 \%$. Cells grew within a $\mathrm{pH}$ range of 6.0-7.5 when no additional buffers were used. When the medium was buffered, growth occurred at a pH of 6.0 and 6.5 (buffer at $10 \mathrm{mM}$ ), and at a pH of 6.5 (buffer at 25 $\mathrm{mM})$.

The $p m o A$ and $m m o X$ genes were amplified by PCR, and we also have cloned the complete sets of genes encoding the particulate methane monooxygenase (pMMO) and the soluble methane monooxygenase (sMMO) (Iguchi, H., Yurimoto, H. \& Sakai, Y., unpublished results). The presence of both pMMO and sMMO in strain $\mathrm{HT}_{1} 2^{\mathrm{T}}$ is a notable characteristic, since in type I methanotrophs, sMMOs have been identified within only three genera (Methylomonas, Methylococcus and Methylomicrobium). The activity of 3 -hexulose-6-phosphate synthase and 6-phospho-3-hexuloisomerase were detected, which are the key enzymes in the ribulose monophosphate pathway.

Strain $\mathrm{HT} 12^{\mathrm{T}}$ is characterized by a unique fatty acid profile compared with other type I methanotrophs (Table 2). The major fatty acids were $16: 0$ and $14: 0$. These fatty acids are the major types in the genera Methylococcus and Methylomonas, respectively, but no other methanotroph has both these fatty acids as major constituents. The fatty acids $16: 1 \omega 7 c$ and $16: 1 \omega 5 t$ are also predominant in many type I methanotrophs (Hanson \& Hanson, 1996; Table 2). However, strain HT12T did not contain these unsaturated $\mathrm{C}_{16}$ fatty acids.

Phylogenetic analysis of the $16 \mathrm{~S}$ rRNA gene sequence and the partial $p m o A$ and $m m o X$ gene sequences indicated that strain $\mathrm{HT}_{12} 2^{\mathrm{T}}$ represents a new lineage within 
the type I methanotrophs. In the phylogenetic tree of the $16 \mathrm{~S}$ rRNA gene, strain $\mathrm{HT} 12^{\mathrm{T}}$ was clustering between the groups Methylosoma, Crenothrix and Methylobacter (Fig. 2). The sequence similarities to the closest strains were $93.1 \%$ to Methylosoma difficile LC $2^{\mathrm{T}}$ and $92.6 \%$ to Methylobacter tundripaludum SV96 ${ }^{\mathrm{T}}$. The $p m o A$ gene sequence of strain HT12 $2^{\mathrm{T}}$ was closely related to that of Methylosoma difficile LC $2^{\mathrm{T}}$ (93\% deduced amino acid sequence identity), Methylomicrobium japanense NIT (93\% identity) and Methylobacter sp. BB5.1 (92\% identity). Strain HT12T formed a distinct branch from these related strains in the $p m o A$ phylogenetic tree (Fig. S1). The phylogeny of the pmoA gene is largely consistent with that of the $16 \mathrm{~S}$ rRNA gene, although strain $\mathrm{HT} 12^{\mathrm{T}}$ was separate from Methylosoma difficile LC $2^{\mathrm{T}}$ in the $p m o A$ phylogenetic tree. The deduced mmoX amino acid sequence between strain $\mathrm{HT}^{2} 2^{\mathrm{T}}$ and the related species of Methylomonas differed by 3-5\% (Fig. S2). The DNA G + C content of strain HT12T was $49.3 \mathrm{~mol} \%$ (Table 1).

The comparative sequence analysis of the $16 \mathrm{~S}$ rRNA gene and the $p m o A$ gene showed that strain $\mathrm{HT}_{12}{ }^{\mathrm{T}}$ was most closely related to the genus Methylosoma and Methylobacter. However, the $7 \%$ sequence differences are too large to classify strain HT12 ${ }^{\mathrm{T}}$ within these genera, and strain $\mathrm{HT} 12^{\mathrm{T}}$ distinctly situated in the phylogenetic trees (Fig. 1 and S1). The fatty acids profile (Table 2) and the sMMO expression also exhibit the novelty of strain HT12 in type I methanotrophs. Therefore we propose that strain $\mathrm{HT} 12^{\mathrm{T}}$ represents a novel genus and a novel species.

\section{Description of Methylovulum gen. nov.}

Methylovulum (Me.thy.lo'vu.lum. N.L. neut. n. methyl the methyl group; N.L. neut. n. ovulum, small egg; N.L. neut. n. Methylovulum, small methyl-using egg). Cells are Gram־negative, aerobic, non־motile, coccoids or short-rods shaped. No 
1 cysts are formed. Cells possess stacks of intracytoplasmic membranes, typical of type I 2 methanotrophs. Cells grow on methane and methanol as the single carbon source.

3 Methane is oxidized by pMMO and sMMO. C1-compounds are assimilated via the

4 ribulose monophosphate pathway. No atmospheric nitrogen fixation occurs. The major 5 cellular fatty acids are $16: 0$ and $14: 0 . \mathrm{DNA} \mathrm{G}+\mathrm{C}$ content is $49 \mathrm{~mol} \%$. Phylogenetically,

6 it belongs to $\gamma$-Proteobacteria (type I methanotroph or Methylococcaceae), and the most closely related genus is Methylosoma. The type species is Methylovulum miyakonense.

Description of Methylovulum miyakonense sp. nov.

Methylovulum miyakonense (mi.ya.ko.nen'se. N.L. neut. adj. miyakonense, of or belonging to Miyako, the ancient capital Kyoto) coccoids or short rods, 1.5-2.5 $\mu \mathrm{m}$ in length and 1.0-2.0 $\mu \mathrm{m}$ in width. Optimum growth is between $24-32^{\circ} \mathrm{C}$ and around $\mathrm{pH}$ 6.5. Cells are sensitive to $\mathrm{NaCl}$ above $0.2 \%(\mathrm{w} / \mathrm{v})$. The type strain is HT12 $\left(=\right.$ NBRC $106162^{\mathrm{T}}=$ DSM $23269^{\mathrm{T}}=$ ATCC BAA-2070 $)$. 


\section{ACKNOWLEDGMENT}

2

3

This work was supported in part by Research Grant Programs for Natural

4 Science from the Asahi Glass Foundation to Y.S. This work was also supported in part

5 by a Grants-in-Aid for Scientific Research (B) 22380052 to Y.S., and Grants-in-Aid for

6 Scientific Research (B) 22310046 to H.Y. from Japan Society for the Promotion of

7 Science.

8 


\section{REFERENCES}

2

Arfman, N., Bystrykh, L., Govorukhina, N. I. \& Dijkhuizen, L.

(1990). 3-Hexulose-6-phosphate synthase from thermotolerant methylotrophic Bacillus C1. Methods Enzymol 188, 391-397.

Auman, A. J., Stolyar, S., Costello, A. M. \& Lidstrom, M. E. (2000).

Molecular characterization of methanotrophic isolates from freshwater lake sediment. Appl Environ Microbiol 66, 5259-5266.

Bowman, J. P., Sly, L. I., Nichols, P. D. \& Hayward, A. C. (1993). Revised taxonomy of the Methanotrophs: description of Methylobacter gen. nov., emendation of Methylococcus, validation of Methylosinus and Methylocystis species, and a proposal that the family Methylococcaceae includes only the group I Methanotrophs. Int J Syst Bacteriol 43, 735-753.

Costello, A. M. \& Lidstrom, M. E. (1999). Molecular characterization of functional and phylogenetic genes from natural populations of methanotrophs in lake sediments. Appl Environ Microbiol 65, 5066-5074.

Dunfield, P. F., Yuryev, A., Senin, P., Smirnova, A. V., Stott, M. B., Hou, S., Ly, B., Saw, J. H., Zhou, Z., Ren, Y., Wang, J., Mountain, B. W., Crowe, M. A., Weatherby, T. M., Bodelier, P. L., Liesack, W., Feng, L., Wang, L. \& Alam, M. (2007). Methane oxidation by an extremely acidophilic bacterium of the phylum Verrucomicrobia. Nature 450, 879-882.

Ezaki, T., Saidi, S. M., Liu, S. L., Hashimoto, Y., Yamamoto, H. \& Yabuuchi, E. (1990). Rapid procedure to determine the DNA base composition from small amounts of gram-positive bacteria. FEMS Microbiol Lett 55, 127-30.

Green, P. N. (1992). Taxonomy of methylotrophic bacteria. In Methane and 
Methanol Utilizers,1st edn, pp. 23-84. Edited by Murrell, J. C. \& Dalton, H. New York: Plenum Press.

Hanson, R. S. \& Hanson, T. E. (1996). Methanotrophic bacteria. Microbiol Rev 60, 439-471.

Holmes, A. J., Costello, A., Lidstrom, M. E. \& Murrell, J. C. (1995).

Evidence that particulate methane monooxygenase and ammonia monooxygenase may be evolutionarily related. FEMS Microbiol Lett 132, 203-208.

Horz, H. P., Rich, V., Avrahami, S. \& Bohannan, B. J. (2005). Methane-oxidizing bacteria in a California upland grassland soil: diversity and response to simulated global change. Appl Environ Microbiol 71, 2642-2652.

Islam, T., Jensen, S., Reigstad, L. J., Larsen, O. \& Birkeland, N. K. (2008). Methane oxidation at 55 degrees $\mathrm{C}$ and $\mathrm{pH} 2$ by a thermoacidophilic bacterium belonging to the Verrucomicrobia phylum. Proc Natl Acad Sci U S A 105, 300-304.

Katayama-Fujimura, Y., Komatsu, Y., Kuraishi, H. \& Kaneko, T. (1984). Estimation of DNA base composition by high performance liquid chromatography of its nuclease P1 hydrolysate. Agric Biol Chem 48, 3169-3172.

Kato, N. (1990). 3-Hexulose-6-phosphate synthase from Mycobacterium gastri MB19. Methods Enzymol 188, 397-401.

Knief, C., Lipski, A. \& Dunfield, P. F. (2003). Diversity and activity of methanotrophic bacteria in different upland soils. Appl Environ Microbiol 69, 6703-6714.

Kolb, S., Knief, C., Dunfield, P. F. \& Conrad, R. (2005). Abundance and activity of uncultured methanotrophic bacteria involved in the consumption of atmospheric methane in two forest soils. Environ Microbiol 7, 1150-1161.

Mohanty, S. R., Bodelier, P. L., Floris, V. \& Conrad, R. (2006). 
1 Differential effects of nitrogenous fertilizers on methane-consuming microbes in rice 2 field and forest soils. Appl Environ Microbiol 72, 1346-1354.

3

Mohanty, S. R., Bodelier, P. L. \& Conrad, R. (2007). Effect of temperature on composition of the methanotrophic community in rice field and forest soil. FEMS Microbiol Ecol 62, 24-31.

Pol, A., Heijmans, K., Harhangi, H. R., Tedesco, D., Jetten, M. S. \& OpdenCamp, H. J. M. (2007). Methanotrophy below pH 1 by a new Verrucomicrobia species. Nature $450,874-878$.

Poly, F., Monrozier, L. J. \& Bally, R. (2001). Improvement in the RFLP procedure for studying the diversity of nifH genes in communities of nitrogen fixers in soil. Res Microbiol 152, 95-103.

Rahalkar, M., Bussmann, I. \& Schink, B. (2006). Methylosoma difficile gen. nov., sp. nov., a novel methanotroph enriched by gradient cultivation from littoral sediment of Lake Constance. Int J Syst Evol Microbiol 57, 1073-1080.

Singh, J. S. \& Kashyap, A. K. (2007). Contrasting pattern of methanotrophs in dry tropical forest soils: effect of soil nitrogen, carbon and moisture. Microbiol Res 162, 276-283.

Stoecker, K., Bendinger, B., Schöning, B., Nielsen, P. H., Nielsen, J. L., Baranyi, C., Toenshoff, E. R., Daims, H. \& Wagner, M. (2006). Cohn's Crenothrix is a filamentous methane oxidizer with an unusual methane monooxygenase. Proc Natl Acad Sci USA 103, 2363-2367.

Vela, G. R. \& Wyss, O. (1964). Improved stain for visualization of azotobacter encystment. J Bacteriol 87, 476-477.

Vigliotta, G., Nutricati, E., Carata, E., Tredici, S. M., DeStefano, M., Pontieri, P., Massardo, D. R., Prati, M. V., DeBellis, L. \& Alifano, P. (2007). 
1 Clonothrix fusca Roze 1896, a filamentous, sheathed, methanotrophic 2 gamma-proteobacterium. Appl Environ Microbiol 73, 3556-3565.

3 Wartiainen, I., Hestnes, A. G., McDonald, I. R. \& Svenning, M. M.

4 (2006). Methylobacter tundripaludum sp. nov., a methane-oxidizing bacterium from 5 Arctic wetland soil on the Svalbard islands, Norway (78 degrees N). Int $J$ Syst Evol $6 \quad$ Microbiol 56, 109-113.

Weisburg, W. G., Barns, S. M., Pelletier, D. A. \& Lane, D. J. (1991).

$8 \quad$ 16S ribosomal DNA amplification for phylogenetic study. J Bacteriol 173, 697-703.

Whittenbury, R., Phillips, K. C. \& Wilkinson, J. F. (1970).

10 Enrichment, isolation and some properties of methane-utilizing bacteria. $J$ Gen Microbiol 61, 205-218. 
Table 1. Differentiation of strain $\mathrm{HT} 12^{\mathrm{T}}$ from other genera of type I methanotrophs

Data for reference genera are from Green (1992) (Methylomonas and Methylobacter), Bowman et al. (1993) (Methylomonas, Methylobacter and Methylomicrobium), Wartiainen et al. (2006) (Methylobacter) and Rahalkar et al. (2007) (Methylosoma).

\begin{tabular}{|c|c|c|c|c|c|}
\hline Characteristic & Methylomonas & Methylobacter & Methylomicrobium & Methylosoma & $\begin{array}{l}\text { Strain } \\
\mathrm{HT} 12^{\mathrm{T}}\end{array}$ \\
\hline \multirow[t]{2}{*}{ Cell morphology } & Rods & Rods or cocci & Rods & Cocci, elliptical & Cocci or short \\
\hline & & & & or rods & rods \\
\hline Motility & + & Variable & + & - & - \\
\hline Cyst formation & + & Variable & - & + & - \\
\hline \multirow[t]{2}{*}{ Pigmentation } & Pink, white & Brown, yellow, & White & Pale pink & Pale brown \\
\hline & & pink & & & \\
\hline $\mathrm{CH}_{4}$ oxidation & $\mathrm{pMMO} / \mathrm{sMMO}$ & $\mathrm{pMMO}$ & pMMO/sMMO & $\mathrm{pMMO}$ & $\mathrm{pMMO} / \mathrm{sMMO}$ \\
\hline nifH gene & Variable & Variable & - & + & + \\
\hline $\mathrm{G}+\mathrm{C}$ content & $52-59$ & $45-55$ & $49-60$ & 49.9 & 49.3 \\
\hline$(\mathrm{mol} \%)$ & & & & & \\
\hline
\end{tabular}


Table 2. Comparison of cellular fatty acids of strain $\mathrm{HT} 12^{\mathrm{T}}$ with those in other type I methanotrophs

Values are percentages of the total fatty acids. Data for reference genera are from Bowman et al. (1993) (Methylomonas, Methylobacter, Methylomicrobium and Methylococcus) and Rahalkar et al. (2007) (Methylosoma). -, not detected (below detection limit); ND, not determined.

\begin{tabular}{|c|c|c|c|c|c|c|}
\hline $\begin{array}{l}\text { Fatty } \\
\text { acid }\end{array}$ & Methylomonas & Methylobacter & Methylomicrobium & Methylococcus & Methylosoma & $\begin{array}{l}\text { Strain } \\
\mathrm{HT} 12^{\mathrm{T}}\end{array}$ \\
\hline $12: 0$ & ND & ND & ND & ND & 2.74 & - \\
\hline $14: 0$ & $19-25$ & $7-10$ & $1-2$ & $1-6$ & 8.55 & 34.2 \\
\hline $15: 0$ & $0-1$ & $0-4$ & - & $0-13$ & 0.79 & 2.97 \\
\hline $16:$ & $19-41$ & - & $12-19$ & - & - & - \\
\hline \multicolumn{7}{|l|}{$1 \omega 8 c$} \\
\hline $16:$ & $8-15$ & $56-58$ & $14-20$ & $11-46$ & 60 & - \\
\hline \multicolumn{7}{|l|}{$1 \omega 7 c$} \\
\hline $16:$ & $5-13$ & $4-5$ & $6-14$ & $0-12$ & 15 & - \\
\hline \multicolumn{7}{|l|}{$1 \omega 6 c$} \\
\hline $16:$ & $2-6$ & $6-8$ & $6-7$ & $0-9$ & - & - \\
\hline \multicolumn{7}{|l|}{$1 \omega 5 c$} \\
\hline $16:$ & $8-17$ & $10-11$ & $6-28$ & $0-6$ & - & - \\
\hline
\end{tabular}




\begin{tabular}{|c|c|c|c|c|c|c|}
\hline $16: 0$ & $4-9$ & $8-9$ & $11-18$ & $34-56$ & 8.5 & 46.9 \\
\hline 16 : & ND & ND & ND & ND & 2.44 & - \\
\hline \multicolumn{7}{|l|}{$1 \omega 11 c$} \\
\hline $16: 0$ & ND & ND & ND & ND & $\mathrm{ND}$ & 8.00 \\
\hline \multicolumn{7}{|l|}{$3-\mathrm{OH}$} \\
\hline 17 & - & - & - & - & ND & 6.40 \\
\hline $1 \omega 6 c$ & & & & & & \\
\hline
\end{tabular}




\section{Figure legends}

Fig. 1. Cell morphology of strain $\mathrm{HT}_{12} 2^{\mathrm{T}}$. (a) Phase contrast micrograph of cells grown in liquid medium. (b, c) Electron micrographs of ultrathin section of cells. Bars, $5 \mu \mathrm{m}$ (a), $1 \mu \mathrm{m}(\mathrm{b})$ and $0.5 \mu \mathrm{m}$ (c).

Fig. 2. Phylogenetic tree of $16 \mathrm{~S}$ rRNA gene sequences showing the relationship of strain $\mathrm{HT}_{12} 2^{\mathrm{T}}$ to other type I methanotrophs. Bar, 0.05 changes per nucleotide sequence position. Bootstrap values less than 50\% are not shown. GenBank accession numbers are given in parentheses.

Fig. S1. Phylogenetic tree of the derived amino acid sequences of $p m o A$ gene from strain $\mathrm{HT}_{12}^{\mathrm{T}}$ and other methanotrophs. The AmoA sequences were used as the outgroup. Bar, 0.05 changes per amino acid sequence position. Bootstrap values less than $50 \%$ are not shown. GenBank accession numbers are given in parentheses.

Fig. S2. Phylogenetic tree of the derived amino acid sequences of $m m o X$ gene from strain $\mathrm{HT}_{12} 2^{\mathrm{T}}$ and other methanotrophs. Bar, 0.05 changes per amino acid sequence position. Bootstrap values less than 50\% are not shown. GenBank accession numbers are given in parentheses. 

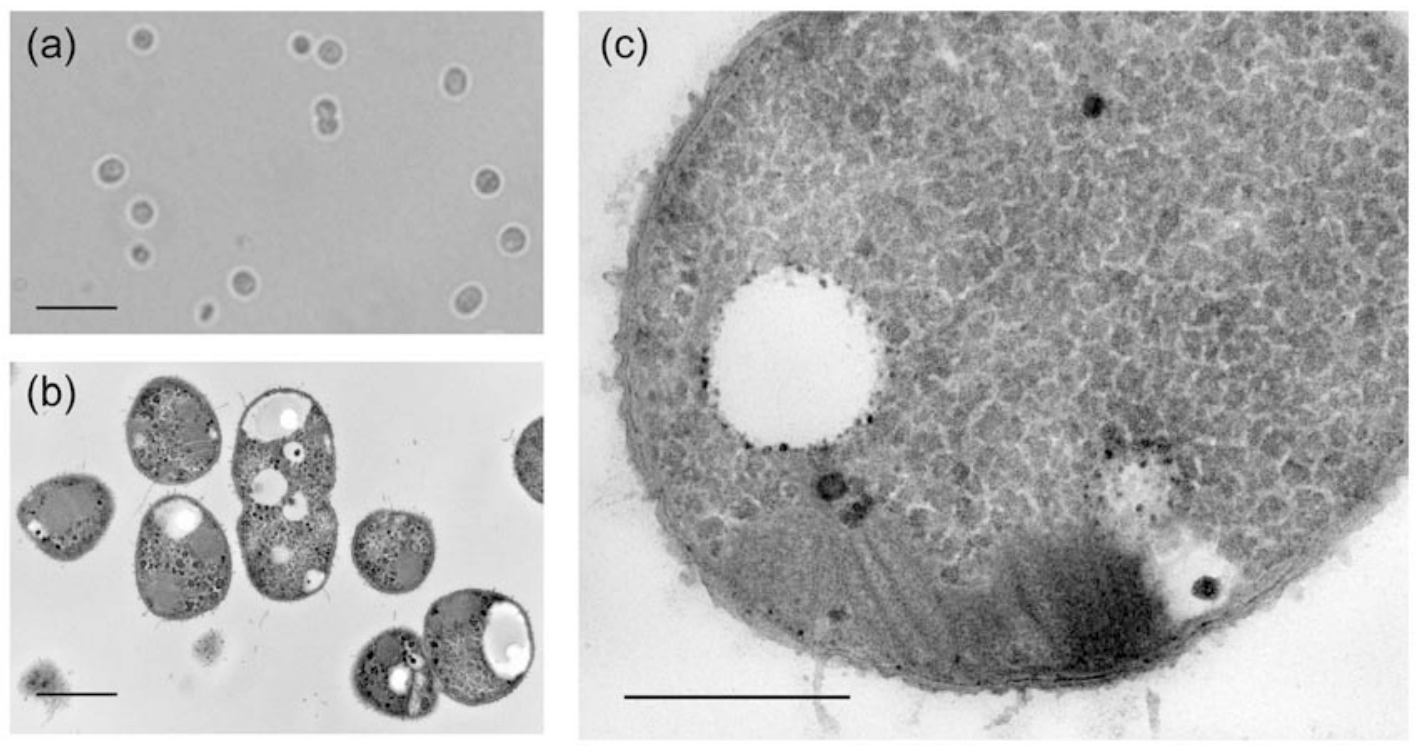


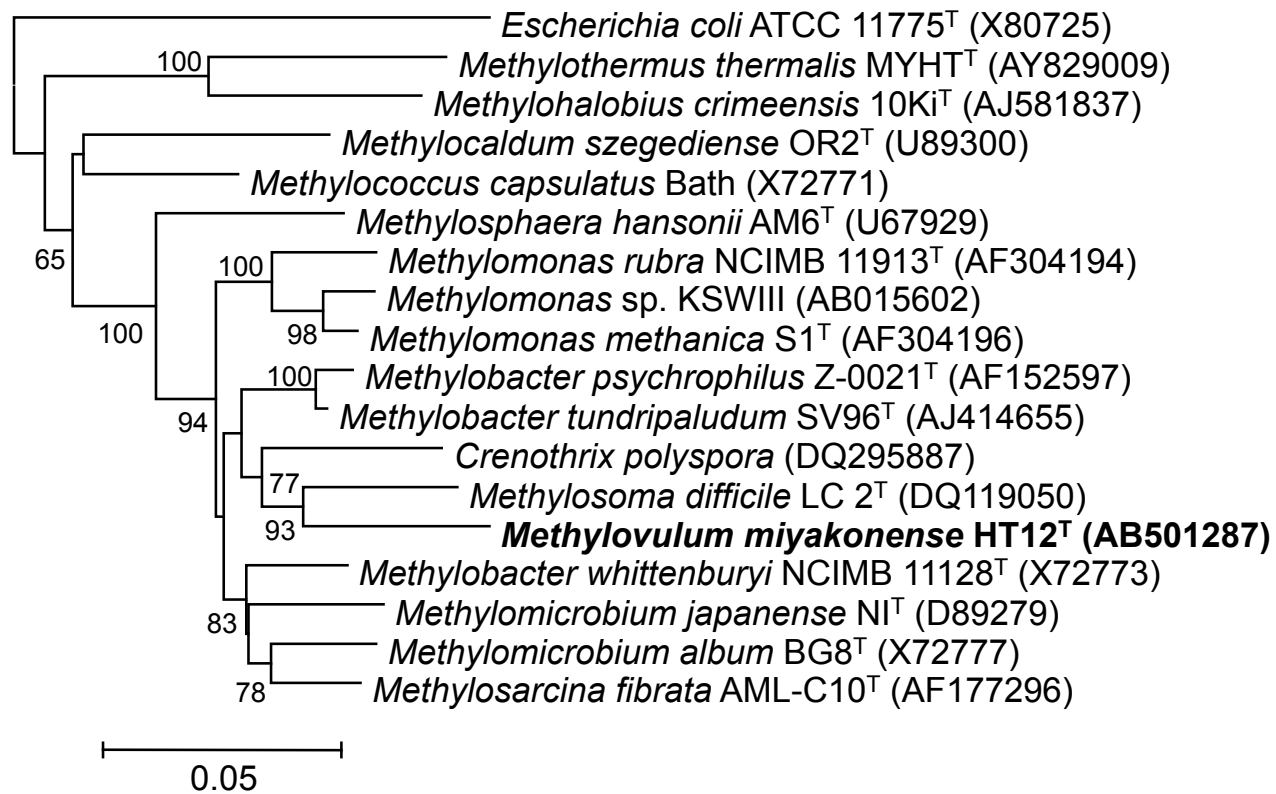

Fig. 2 


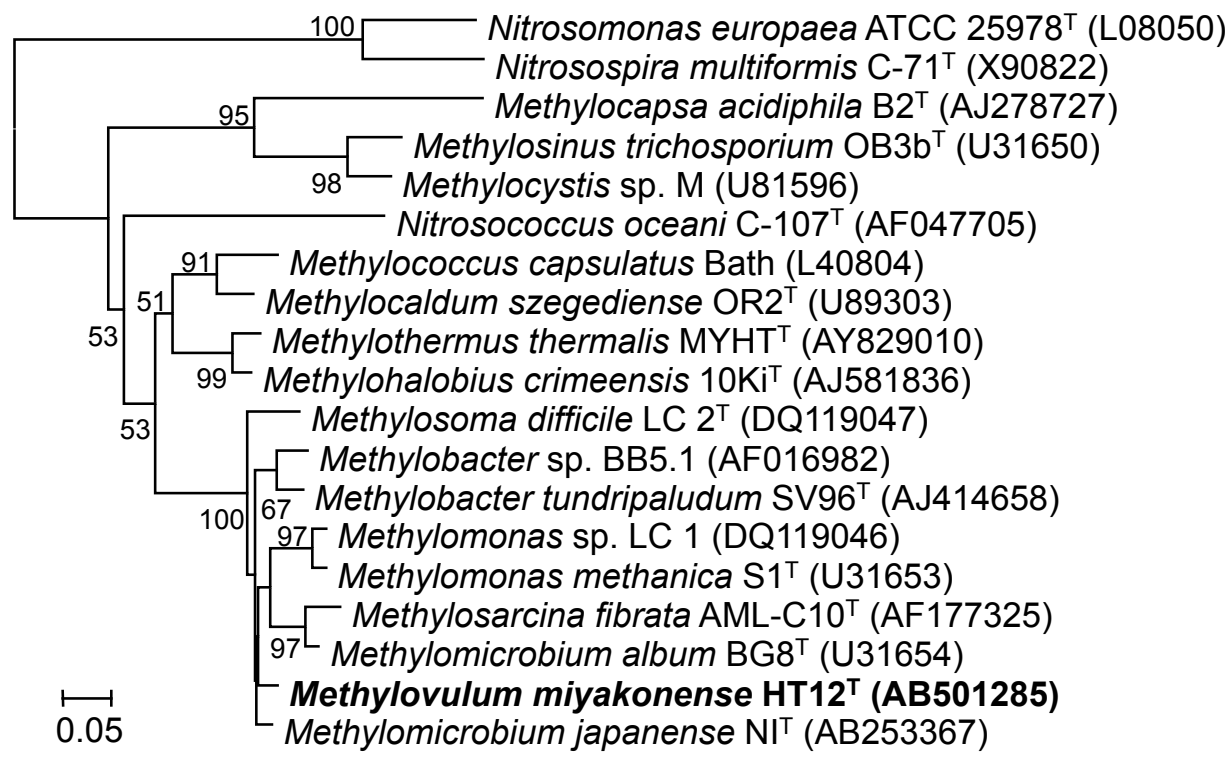

Fig. S1 


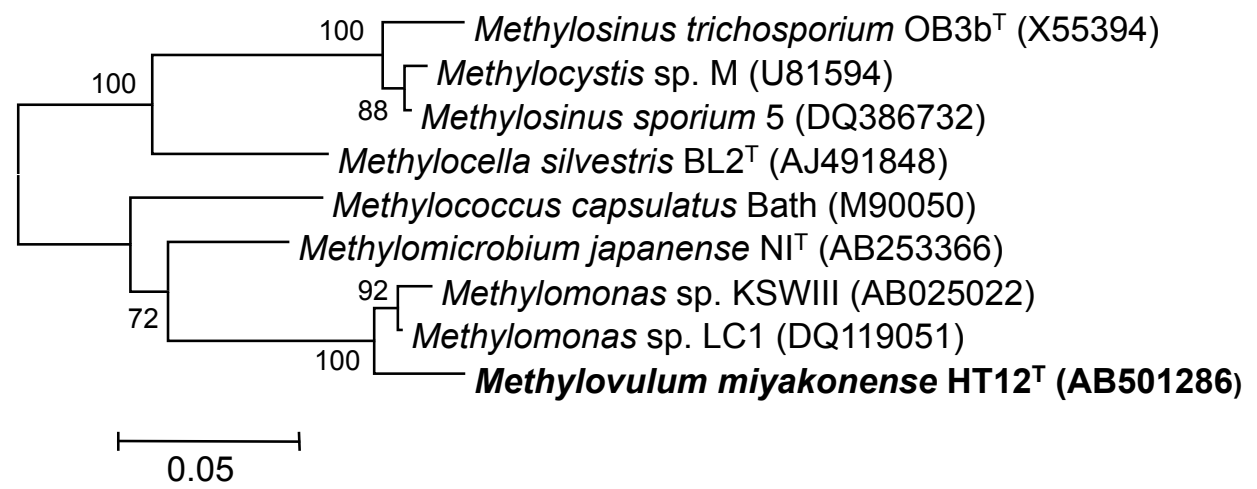

Fig. S2 